\title{
«Blod er en ganske spesiell saft»- innføring av serumbehandling for difteri i Norge
}

\author{
På 100-årsjubileumsutstillingen for Grunnloven offentliggjorde Ullevål sykehus i 1914 imponerende resultater \\ av moderne serumbehandling mot difteri. Noen år tidligere hadde utviklingen av behandlingen lagt grunnlaget \\ for moderne serologi - og skaffet en av oppdagerne den første nobelprisen i fysiologi eller medisin.
}

I år markeres 200-årsdagen for Grunnloven. 100-årsjubileet ble feiret i Frognerparken med en imponerende og bredt anlagt utstilling som ifølge invitasjonen til utstillerne «ikke blot vil omfatte frembringelser av landets hoved- og binæringer, men dertil gi et billede av vore offentlige og private institutioners virksomhet og betydning i samfundet» (1). Kristiania kommune hadde en egen paviljong, og der stilte Ullevål sykehus med dokumentasjon av en ny og effektiv behandling for difteri - serumbehandlingen (fig 1).

Peter Hansen Aaser (1843-1923) var mannen bak det norskproduserte difteriserumet. Aaser ble stadslege i Kristiania i 1882, og i 1891 ble han ansatt som overlege og bestyrer ved Ullevål epidemisykehus, der han introduserte serumbehandlingen fra 1895 (2). Med stipend fra staten og Kristiania kommune studerte han i 1893 bakteriologi ved Pasteur-instituttet i Paris, og i 1894 reiste han på ny til Paris for å sette seg inn i fremstillingen av difteriserum.

Da Aaser kom hjem fra Paris, opprettet han et seruminstitutt ved epidemiavdelingen ved Ullevål sykehus. Der ble det produsert difteriserum (2). Den såkalte serumhesten på sykehuset ble immunisert med difteritoksin og tappet for blod, som var kilden for difteriserumet. Hesten fikk god forpleining i egen stall på sykehusområdet. Serumet ble i starten produsert for bruk på Ullevål, inntil Aasers produksjon ble tilstrekkelig stor til å dekke hele landets behov (3).

\section{Effektiv behandling}

Et stolpediagram som viste effekten av serumbehandlingen var hengt opp på veggen på Ullevåls stand på jubileumsutstillingen (fig 2). Fra 1887, da sykehuset ble opprettet, og frem til 1895 døde $20-35 \%$ av difteripasientene. Etter at serumbehandlingen ble innført, falt dødeligheten til 3-5\%.

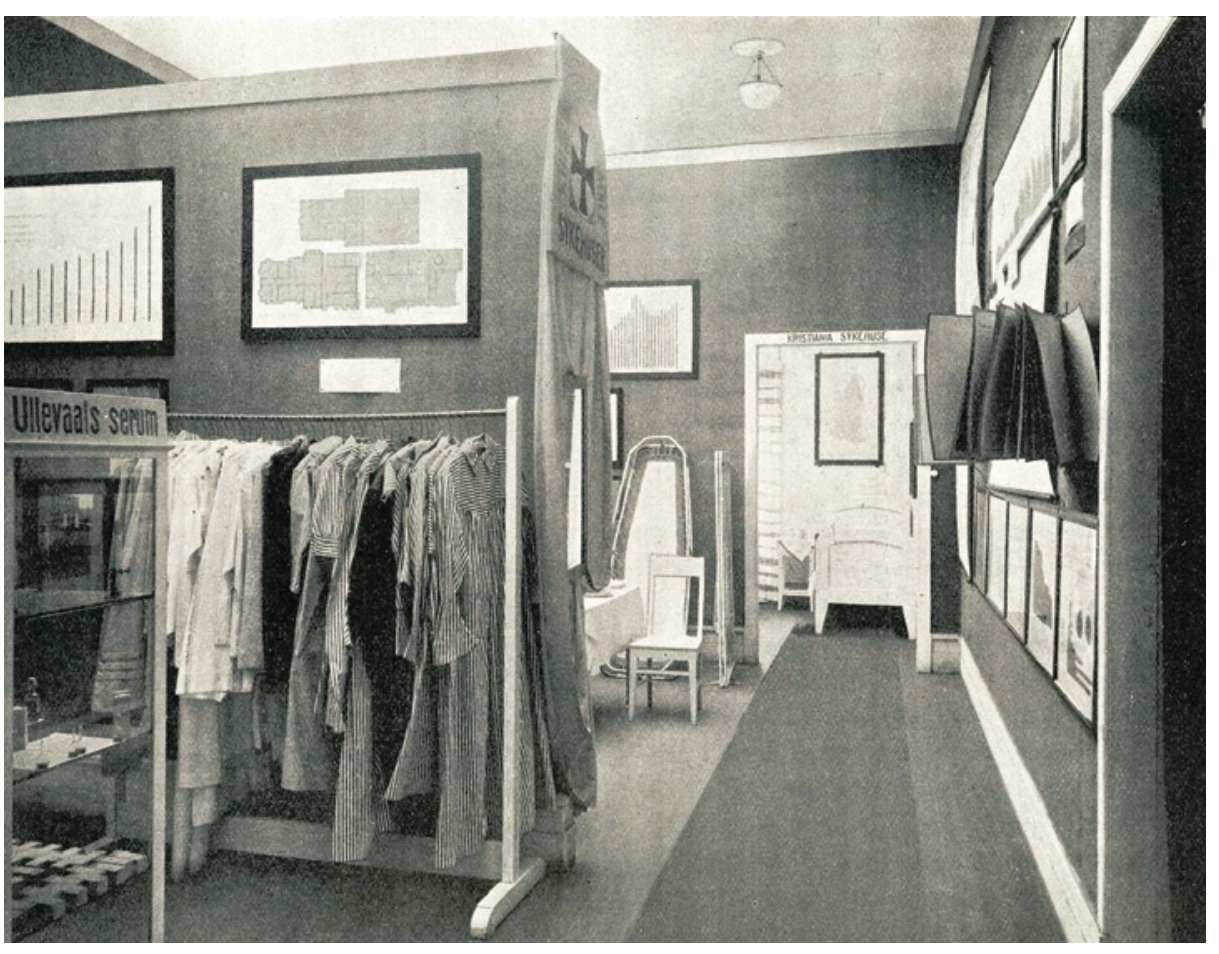

Figur 1 Fra Ullevål sykehus' stand på Jubilæumsutstillingen i 1914. Monteren merket «Ullevaals serum» ses i venstre bildekant. Bilde fra Norges Jubilæumsutstilling 1914. Officiel Beretning (1)
Resultatet imponerer oss i dag, som det sikkert har imponert dem som besøkte utstillingen for hundre år siden.

I en artikkel i Tidsskriftet i 1896 redegjorde Aaser for de 352 difteripasientene som fra januar 1895 til oktober samme år var innlagt ved epidemiavdelingen (4). I dette totalmaterialet inngår både lette tilfeller, der det ikke ble gitt serumbehandling, og 212 pasienter som var alvorligere rammet og fikk slik behandling. Dødeligheten i gruppen totalt var 5,9\%, i behandlingsgruppen 9,9\%. Dødeligheten var sterkt avhengig av hvor tidlig i sykdomsforløpet behandlingen ble gitt. Ingen som fikk behandling på første sykdomsdag døde, og bare $0,9 \%$ av dem som ble behandlet på dag 2. Dødeligheten økte deretter raskt til $40 \%$ for pasienter behandlet på dag 5 .

I samme artikkel omtaler Aaser 2504 pasienter innlagt på Ullevål fra 1889 til september 1894 (4). I denne perioden ble serumbehandling ikke gitt. Samlet dødelighet var $24 \%$, og den var avhengig av hvor raskt pasientene kom på sykehuset. Av pasienter innlagt første sykdomsdag døde $19 \%$, mot $30 \%$ av pasienter innlagt dag 4 . Det var således meget viktig å gripe inn tidlig i sykdomsforløpet, enten man behandlet med difteriserum eller ikke.

Aaser konkluderer med: «af de fremlagte tal fremgaar det, at mine forsøg med serum har havt et meget heldigt resultat, langt heldigere end jeg paa forhaand havde ventet; thi fra først af antog jeg, at serumterapien kun vilde blive en ny skuffelse i difteribehandlingen. Vi maa altsaa blive staaende ved, at serumterapien dog giver gunstigere resultater end nogen anden behandling» (4).

\section{Nobelpris for serumterapi}

Serumbehandlingen av difteri ble utviklet parallelt med serumbehandlingen av tetanus av to bakteriologer, Emil Behring (1854-1917) og Shibaraburo Kitasato (1853-1931) $(5,6)$. Deres forsøk viste at serum fra immuniserte dyr har evnen til å gi passiv immunitet mot toksinene som produseres av henholdsvis tetanus- og difteribakte- 


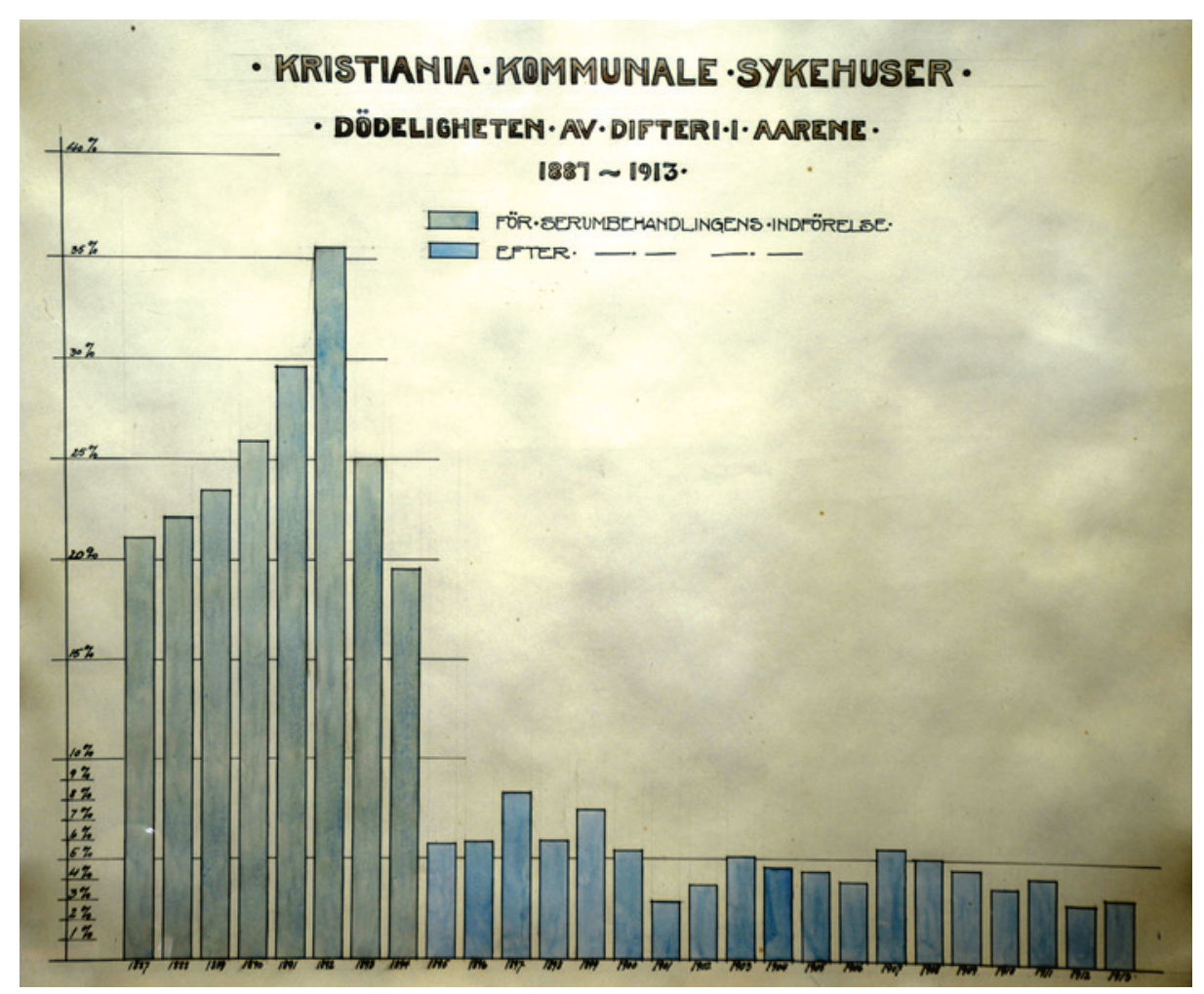

Figur 2 Dødelighet av difteri på Ullevål sykehus før og etter innføring av serumbehandlingen i 1895. Stolpediagram fra Ullevål sykehus' stand på Jubilæumsutstillingen i 1914. Foto: Museet, Ullevål sykehus

rien, og at slike sera forebygger sykdom hos friske dyr og helbreder sykdom hos smittede dyr.

Den aller første nobelprisen i fysiologi eller medisin ble i 1901 tildelt Behring for hans arbeid med serumterapi. I sitt nobelforedrag brukte han begrepet «antitoksin» for det proteinet i antiserum som nøytraliserer bakterietoksinet (7). Han kalte serumbehandlingen for «humoral behandling», med klar henvisning til begrepet «humoral patologi», læren om kroppsvæskenes betydning for sykdom.
Dette meget gamle begrepet hadde etter hvert mistet enhver relevans som følge av den medisinskfaglige utviklingen på 1800tallet. Ikke minst hadde Rudolf Virchow (1821-1902) bidratt til et paradigmeskifte i sykdomsforståelsen gjennom sin lære om den cellulære patologi - at det er i cellene sykdommen ligger, ikke i kroppsvæskene. Det virker som om Behring gledet seg over å kunne finne ny anvendelse for det tradisjonelle begrepet «humoral» gjennom sin innsats for en epokegjørende ny behandlingsstrategi - serumbehandlingen.
I en historisk oversikt over mikrobiologien (8) hevdes det at fagområdet medisinsk serologi startet med fellespublikasjonen til Behring \& Kitasato (5). De avslutter sin artikkel med litt av et fyndord: «Blut ist ein ganz besonderer Saft» (blod er en ganske spesiell saft) (5). Det er intet dårlig slagord for den medisinske serologien.

\section{Paul Linnestad}

paul-jl@online.no

Paul Linnestad (f. 1940) er museumsvokter, Ullevål museum, og pensjonert overlege fra Gastromedisinsk avdeling, Oslo universitetssykehus, Ullevål.

Forfatter har fylt ut ICMJE-skjemaet og oppgir ingen interessekonflikter.

\section{Litteratur}

1. Brinchmann NA. Norges Jubilæumsutstilling 1914. Officiel Beretning. Kristiania: Grøndahl, 1924

2. Larsen $\emptyset$, red. Norges leger. Bd. 1. Oslo: Den norske legeforening, 1996.

3. Breivik E, Gradmann C. Halsesyke i Europas utkant - da difteriantitoksinet kom til Romsdals amt. Tidsskr Nor Legeforen 2014; 134: 732-5.

4. Aaser P. Om serumterapi ved difteri. Tidsskr Nor Lægeforen 1896; 16: 1-23.

5. Behring E, Kitasato S. Ueber das Zustandekommen der Diphtherie-Immunität und der TetanusImmunität bei Thieren. Dtsch Med Wochenschr 1890: 16:1113-4.

6. Behring E. Untersuchungen über das Zustandekommen der Diphtherie-Immunität bei Thieren. Dtsch Med Wochenschr 1890; 16: 1145-8.

7. Behring E. Serum therapy in therapeutics and medical science. Nobelforedrag 12.12.1901. www.nobelprize.org/nobel_prizes/medicine/ laureates/1901/behring-lecture.html (19.5.2014).

8. Brock TD, red. Milestones in microbiology. Boston, MA: ASM Press, 1998: 141.

Mottatt 21.3. 2014 og godkjent 22.5. 2014. Redaktør: Are Brean. 